\title{
Indigenous Peoples and the Regulation of REDD+ in Brazil: Beyond the War of the Worlds?
}

\author{
Alex Shankland and Leonardo Hasenclever*
}

Abstract This article focuses on the actors, interests and ideologies shaping Reducing Emissions from Deforestation and Forest Degradation (REDD) regulation in Brazil, with a particular focus on indigenous territories. It examines the convergence of four parallel and potentially conflicting initiatives: a consultation exercise led by the federal Environment Ministry; the development of sub-national regulatory frameworks by states in the Amazon region; the introduction of a 'REDD Certification' bill in Congress; and a civil society effort to establish principles and criteria for 'socioenvironmental' safeguards. The article interrogates the extent to which this convergence has resolved underlying tensions or merely postponed engaging with them, drawing on Bruno Latour's concept of a 'war of the worlds' to examine the highly contested relationship between market-based approaches and the rights of indigenous peoples.

\begin{abstract}
1 Introduction
The search for progress on a global regime for the promotion of Reducing Emissions from Deforestation and Forest Degradation (REDD) was a major focus of the December 2010 COP16 summit in Cancun, Mexico. ${ }^{1}$ This summit also saw Brazil building on the leadership role it has increasingly assumed in debates on the links between deforestation and climate change. Globally, the LULUCF (land use, land use change and forestry) category of activities accounts for 17.4 per cent of annual greenhouse gas (GHG) emissions (IPCG 2007). In Brazil, which is currently the world's fourth-largest GHG emitter, this category accounts for up to 55 per cent of the country's annual emissions, with the inclusion of agriculture bringing the total to around 80 per cent (McKinsey \& Company 2009).
\end{abstract}

To date, most international attention has been focused on the Amazon region of Brazil. This region not only includes over half of the world's largest rainforest, but is also home to a number of highly active social movements who claim to speak for the indigenous peoples and other forest-dwellers who have been resisting the roadand dam-building, logging, mining, smallholder resettlement and cattle-ranching that by 2007 had driven the destruction of over 18 per cent of the original forest cover of the Brazilian Amazon (Fearnside 2008).

Indigenous territories cover over one-fifth of Brazilian Amazonia (some 220 million hectares of forest), and 25.3 per cent of the total territory of the Amazon (Rojas Garzón 2009). They have been shown to be the most effective category of protected area in reducing deforestation - with an impact significantly greater than that of indirect-use conservation areas such as national parks (Nelson and Chomitz 2009). As the national regulatory framework for REDD+ and the national policy on the management of indigenous territories (the Política Nacional de Gestão Ambiental em Terras Indígenas or PNGATI) are still being debated, Brazil's Amazonian indigenous groups have found themselves facing increasingly intense interest in their lands from private sector 'carbon cowboys' (Harvey 2007) and mainstream environmental NGOs alike.

The emerging Brazilian regulatory framework for REDD+ has been influenced by four parallel and potentially conflicting initiatives: 
- A consultation exercise led by the federal Environment Ministry;

- The development of sub-national regulatory frameworks by states in the Amazon region;

- The introduction of a 'REDD Certification' bill in Congress;

- A civil society effort to establish principles and criteria for 'socioenvironmental' safeguards in REDD+ initiatives.

Each was driven by a distinct constellation of actors and interests, espousing a range of different and often contradictory ideological standpoints (see Tanner and Allouche, this IDS Bulletin). Despite the extent of these differences, however, by December 2010, they had given way to apparent agreement on a way forward for regulating REDD+ in Brazil.

The article highlights the particular challenges posed by the implementation of REDD+ initiatives in indigenous territories. It focuses on the actors, ideologies and interests influencing these processes, and interrogates the extent to which their convergence has resolved underlying tensions. Following Bruno Latour, it asks whether or not the 'war of the worlds' over REDD+ in Brazil has evolved into a new phase of constructive engagement between holders of different worldviews - or whether it has merely perpetuated the illusion that this engagement is not really necessary, since 'when disputes occur, we need only to increase the relative share of scientific objectivity, technical efficiency, economic profitability and democratic debate, and the disputes will soon cease' (Latour 2002: 7). In exploring these tensions, it highlights the strategic significance of one of the most vexed issues in global debates on REDD+, the relationship between market-based approaches and the rights of indigenous peoples.

\section{REDD in Brazil: actors and ideologies}

The fieldwork for this case study was carried out between September and December 2010, and included key informant interviews, a stakeholder workshop and participant observation in civil society and government-sponsored REDD+ discussion events in Brasília and Amazonas, as well as analysis of policy documents and other texts. This included the construction of a Stakeholder Matrix (Holland 2007) with a group of workshop participants from Brazilian and international NGOs, bilateral donor agencies and Amazonian social movements.

The main groups of actors identified as engaging in REDD+ debates in Brazil, although with varying levels of involvement, power and influence, were those associated with the Federal Government, sub-national governments, agribusiness and other economic interests, bilateral and multilateral donor and lending agencies, large international NGOs (or 'INGOs'), Brazilian environmental NGOs, indigenous movement organisations and other social movements. The research showed that positions within each of these groupings are heterogeneous and often highly contested, with struggles for control of the agenda driven both by competition for power and resources and by ideological differences. Applying the stakeholder matrix methodology to a specific issue (in the case of the workshop discussion, the marketing of carbon credits deriving from REDD+ activities in indigenous territories) makes it possible to identify some of the key faultlines.

Brazil's position in international negotiations has long been wary of market-based approaches, favouring intergovernmental arrangements such as the 2008 agreement with Norway, under which it established a billion-dollar 'Amazon Fund' to support REDD+ and 'REDD-readiness' activities. However, over the last 2-3 years this position has shifted as different perspectives within the Federal Government have come to the fore. Our research suggests that both the indigenous affairs agency FUNAI and the long-engaged Ministry of Science and Technology and Ministry of Foreign Affairs remained sceptical of market-based REDD+ initiatives, especially when these affected sensitive areas such as indigenous territories. The powerful President's Office was broadly neutral and the Environment Ministry, which has come to play an increasingly central role in both national climate change policy and intergovernmental negotiations, was also less hostile to market-based REDD+ approaches. ${ }^{2}$

Among the sub-national governments, the Amazonian states had clearly taken the lead in debates on REDD, attempting to work out a common policy position through the Legal Amazon Governors' Forum. ${ }^{3}$ In June 2009, this forum issued a strong statement, known as the 'Palmas Declaration', which interviewees 
credited with shifting the federal government away from its initial position of blanket hostility to market-based mechanisms ahead of the Copenhagen COP15 summit. ${ }^{4}$ Despite such displays of unity, however, Amazonian state governments have espoused very different approaches to REDD+. These range from the ambivalence of the agribusiness-dominated government of Mato Grosso, to the aggressive pursuit of private-sector partnerships by the business-friendly government of Amazonas, to the attempt to build a participatory forest management model by the social movementaligned government of Acre.

Among the environmentalist INGOs, the Worldwide Fund for Nature (WWF) appears as the most cautious and The Nature Conservancy (TNC) as the most strongly market-focused. Indigenous organisations were shown to be deeply divided, with apex organisations like COIAB (the coordinating body for indigenous movement organisations in the Amazon region) and APIB (the national indigenous movement body) struggling to arrive at a common position, while different leaders among their grassroots constituencies formed alliances with pro-REDD or anti-REDD NGOs, or found themselves engaging directly with the carbon market. Some groups claimed to be managing this engagement successfully (e.g. the Paiter-Suruí in the Western Amazonian state of Rondônia), but other indigenous leaders interviewed during the research spoke of perplexity, alarm and intracommunity conflict resulting from contacts with outsiders promising carbon market cash for REDD+ activities. ${ }^{5}$ Many of these outsiders were reputable environmental NGOs, but there were also several reports of indigenous leaders receiving unsolicited contact from private sector 'carbon cowboys'.

The Brazilian NGOs cited by key informants had an even wider range of positions in relation to the regulation of carbon credits deriving from REDD+ activities in indigenous territories. Some (such as IDESAM and FUNBIO) are actively engaged in mediating relationships with Brazilian and international corporate purchasers of compulsory or voluntary offsets. Others (such as ISA, IPAM and IMAFLORA) have been promoting 'socioenvironmental' safeguards but are broadly in favour of forest-dwelling communities engaging with the carbon market. A further group (including CTI and IEB) ${ }^{6}$ have longstanding engagements with indigenous groups who are now exploring REDD+ opportunities, but are more hesitant about market-based approaches, while a final group (including rights-based NGOs linked to the MST or Landless Rural Workers' Movement and CIMI, the indigenous affairs agency of the Catholic Church) are viscerally opposed to such approaches.

The ideological reference points for these diverse actors echo many of those that have already been identified at the global level, with a predominance of 'social green' worldviews (Clapp and Dauvergne 2005; Hiraldo and Tanner, this IDS Bulletin; Peskett and Brockhaus 2009). In addition, however, our detailed analysis of the Brazilian ideological and discursive environment since mid-2009 has highlighted the importance of a further perspective, which we will call 'socioculturalist'?

This perspective is underpinned by a conviction that, as the October 2009 Belém Declaration put it, 'markets are not the spaces capable of taking responsibility for life on this planet' (Amigos da Terra et al. 2009: 1). This Declaration signals that while there may be significant ideological factors underpinning other standpoints (such as a preoccupation with national sovereignty or a belief in the primacy of environmental preservation over human development), the 'socioculturalist' perspective is the only one of these whose challenge for REDD regulation has an ontological basis. As Bruno Latour points out, the Western modernist tradition, to which advocates of 'technical' and 'market-based' solutions to climate change belong, presents market forces as 'the natural bedrock of all humanity since the beginning of time, as the fundamental logic to which everyone should submit without discussion in order to enjoy the benefits of wealth and freedom' (Latour 2002: 48). For the signatories of the Belém Declaration, however, market mechanisms are a set of culturally and historically specific constructs that serve particular political and economic interests and have no claim to represent a 'fundamental logic' for humanity.

This Declaration was issued by a group of social movement organisations, labour unions and human rights NGOs, many of them linked to the Catholic Church and/or the Workers' Party (PT), 
who met in the Amazonian city of Belém in the run-up to the Copenhagen COP15 meeting. They insisted that the participation of Brazil in international negotiations should not focus on REDD+ or any other (fully or partially) marketbased instrument, but rather should emphasise the need for transition to a new model of production, distribution and consumption, based on agroecological principles, cooperatives, fair trade, energy diversification, biosafety and food sovereignty. This 'socioculturalist' perspective is driven and legitimated by Brazilian actors such as the MST, both domestically and within international coalitions such as the peasant movement organisation Via Campesina, which articulated the most significant anti-REDD protests in Cancun.

'Socioculturalist' ideology was given a strong platform at the 'World Peoples' Conference on Climate Change and the Rights of Mother Earth' in Cochabamba in April 2010. The Cochabamba 'Peoples' Agreement' rejected 'market mechanisms such as REDD... which are violating the sovereignty of peoples and their right to prior free and informed consent as well as the sovereignty of national States, the customs of Peoples, and the Rights of Nature' (CMPCG 2010). The Cochabamba meeting placed particular emphasis on 'the knowledge, wisdom, and ancestral practices of Indigenous Peoples, which are affirmed in the thought and practices of 'Living Well', recognizing Mother Earth as a living being with which we have an indivisible, interdependent, complementary and spiritual relationship' as the reference point for its rejection of market-based responses to climate change.

A few months before the Cancun summit, the divergences outlined above seemed irreconcilable. In particular, the 'socioculturalist' standpoint seemed to be firmly tied to a radical rejection of REDD - which could prove fatally damaging to its viability, given the wide range of Amazonian forest-dwellers' social movements represented among the signatories of the Belém Declaration. However, the view that rejection of market-based approaches was not merely ideological but actually ontological once one subscribed to 'indigenous values' was not necessarily shared by the political representatives of the original holders of those values. Although the indigenous peoples of the Brazilian Amazon have long acquired an emblematic status for socioculturalists and for the global green movement as a whole (at least since the rock star Sting first took the Kayapó leader Raoni on tour two decades ago), no Brazilian indigenous organisations signed either the Belém Declaration or the Cochabamba 'Peoples' Agreement'. It seems that their leaders did not find that 'indigenous values' automatically debarred them from engaging in REDD+ activities - though the terms of that engagement would certainly need to be carefully negotiated.

\section{Regulating REDD in Brazil: towards convergence?}

Brazilian debates on REDD have been shaped by the country's specific ideological and political dynamics, rather than simply reproducing global positions. Nevertheless, the influence of global policy processes can clearly be seen when we analyse the trajectories of different Brazilian initiatives on REDD+ regulation. Timelines highlighting key events and processes (identified through key informant interviews and the stakeholder workshop) were produced by this research in each of the domains: civil society, sub-national governments, the federal government and the national legislature. These showed a heavy clustering of significant events in the months preceding the COPs in Copenhagen (December 2009) and Cancun (December 2010), and key informants concurred that the need to take an agreed position to these global fora was a powerful driver for domestic negotiations. In this section, we describe how these negotiations led to convergence both within and across the four domains of action identified in the Brazilian debate over REDD regulation.

In the sub-national domain, the state of Amazonas initially made the running, passing a State Climate Change Policy into law in June 2007. Multiple REDD-related programmes reflecting business-friendly approach have since emerged, including the Bolsa Floresta programme (a system of cash transfers tied to forest protection that is co-funded by the state government with Brazilian and international businesses) and enabling legislation for a new kind of protected area, the Private Sustainable Development Reserve, which would be eligible for REDD+ funding. The State of Acre, which has been governed by the Workers' Party since 1998 and whose government has developed a virtually symbiotic relationship with forest peoples' movements (Shankland 2010a), has 
recently become more influential, not least by successfully positioning itself as a key partner of Arnold Schwarzenegger's Californian administration within the international Governors' Climate and Forests Task Force (GCF). Following a participatory process that marked a clear distinction between its approach and that of Amazonas, the Acre state government carried out extensive consultations before establishing a sub-national regulatory framework for climate change policy based on a REDD-friendly system of incentives for preserving ecosystem services in October 2010.

While pursing their own distinctive agendas, the different states used the Legal Amazon

Governors' Forum to work out a common platform for engaging with the Brazilian federal government on REDD, successfully pressing President Luís Inácio Lula da Silva to set up a task force to review the country's negotiating position ahead of the Copenhagen COP15 summit. This task force concluded by recommending a more positive approach to market-based financing of REDD + activities, as urged by the Amazonian governors in their 'Macapá Declaration' of October 2009.

Significantly, it also favoured the remuneration not only of 'flows' of reduced deforestation (which appealed to Mato Grosso and other states with high rates of forest destruction), but also of 'stocks' of standing natural forests, which favoured states with most of their rainforest still intact - above all Amazonas, which by 2007 had lost less than 2 per cent of its original forest cover, against 13 per cent for Acre and over 37 per cent for Mato Grosso (Fearnside 2008).

The influence of Amazonas state has also been evident within the federal legislative domain, in particular through the influence of the state's leading REDD advocate Virgílio Vianna (a former Secretary for Sustainable Development in the state government who heads the mixed publicprivate 'Sustainable Amazonas Foundation'). In July 2009, Lupércio Ramos, a Federal Deputy from Amazonas, introduced a 'REDD Certification' bill in Congress. The bill initially made little progress as it was seen as favouring an excessively narrow group of (private) interests. However, at Virgílio Vianna's suggestion, another Federal Deputy from Amazonas, Rebecca Garcia, took responsibility for steering the bill through the Environment and Sustainable Development Committee of the lower house of Congress in December 2009, and immediately set about building a broader base of support for it. Over the course of 2010, her office organised a total of 43 discussion meetings and consultations with key actors ranging from federal government representatives to social movements to carbon-market players. The federal government remained suspicious of the bill, and initially blocked it when it came up for approval in the Environment and Sustainable Development Committee in November 2010. However, this proved only a temporary setback. When the government referred the bill to the Environment Ministry, the latter was able to mobilise a rapid response from the chairs of three working parties that had been set up to discuss key aspects of a future national regulatory framework for REDD+. This, in turn, allowed for revisions to be made to the text of the bill in time for it to pass through the Committee stage before the end of the legislature's term in December 2010.

The Environment Ministry had belatedly established these working parties in July 2010 after a long period in which it devoted more attention to biodiversity and left the more REDD-sceptical Ministry of Science and Technology to lead on climate change policy. They had a mixed government, private-sector and civil society membership; all three were chaired by climate change specialists who were independent of the federal government, and although they were convened by the Ministry, their status was not formalised, which meant that their recommendations were non-binding. This lack of formalisation and the rushed schedule for the groups' deliberations generated some tensions, particularly over the participation and representation of grassroots interests. It was not until November that some members of indigenous and other forest-dwellers' social movements were able to take part in one of the consultation meetings, where they demanded that additional resources be made available to broaden engagement. Despite these demands, the working parties' cycle of meetings was wound up as scheduled in late November, with the result that when their chairs were asked to provide suggestions for revision of the bill being steered through Congress by Rebecca Garcia, they had to resort to consulting group members by e-mail - a mechanism not well suited to securing extensive participation from grassroots members of forest-dwellers' movements. 
As it happens, a consultative process with a much broader-based approach to participation had already been undertaken by a coalition of civil society groups between December 2009 and April 2010. This was the effort, facilitated by a group of Brazilian NGOs and funded by the Packard Foundation, to construct 'Socioenvironmental Principles and Criteria for REDD+ projects in the Brazilian Amazon', which included largescale meetings for representatives of indigenous and non-indigenous forest-dwellers' movement organisations in the major Amazonian cities of Manaus, Porto Velho and Belém, as well as consultations with farmers in the state of Mato Grosso and with private-sector interests in São Paulo. What marked this 'Principles and Criteria' process out as distinctive was the effort that was put into ensuring that the development of recommended safeguards by a multistakeholder committee was matched by extensive consultation. This allowed the facilitators of the process to claim that the more than 150 representatives of indigenous groups and other rainforest residents and users who took part in the meetings 'were not simply consulted during the process, but were mainly responsible for the construction of the document, which has strengthened its legitimacy and their sense of ownership of it' (Voivodic et al. 2010: 15). This participation was orchestrated by the joint NGO-social movement 'Amazon Working Group' (GTA) and other social movement umbrella groups - including several who had been signatories to the 'Belém Declaration' that rejected REDD outright in October 2009.

Although some of these groups continued to voice deep suspicion, the 'Principles and Criteria' process was highly effective in shifting the terms of the debate. Most of the social movement leaders on whom the anti-REDD campaign depended for its legitimacy, realised during the consultation process that they could not afford to exclude themselves from this potentially significant source of resources and political leverage, and shifted their focus to discussing the conditions that would need to be fulfilled before REDD projects could go ahead. In effect, the 'socioculturalist' attack on the legitimacy of REDD was blunted by turning an argument about values into one about safeguards. The 'Principles and Criteria' process had promoted broad-based engagement with representatives of groups whose perspectives had seemed to pose a fundamental challenge to the assumptions underpinning REDD - but in Latour's terms, by excluding the ontological component of these perspectives, the process ensured that debates 'affected representations, but they never touched the substance, the very fabric of the world' (Latour 2002: 17).

The 'Principles and Criteria' consultation was able to secure an unusual level of national legitimacy and visibility for a civil society-led (and foreign-funded) process in Brazil. This was reflected in the fact that its final product was explicitly picked up by actors engaged in the parallel processes that were being led by subnational governments, the Environment Ministry and Congress. In the event, Rebecca Garcia's bill was to incorporate many of the key points from the 'Principles and Criteria' safeguard recommendations, inserted by the federal government on the advice of the Environment Ministry's working parties - many of whose key members had been closely involved both in the 'Principles and Criteria' process and in various sub-national government initiatives.

The convergence of four initially parallel processes in the domains of sub-national government, Congress, the federal government and civil society was thus a coming-together of people, as well as of interests and - apparently of ideologies. In effect, policy was being shaped by an 'epistemic community' (Haas 1992) that had incorporated elements of what we have called the 'socioculturalist' standpoint - a convergence that had been made possible by downgrading the socioculturalist challenge from a fundamental question of ontology to a negotiable question of safeguards.

\section{Forest governance, indigenous peoples and REDD: challenges for implementation}

By late 2010, the struggles over REDD+ regulation in Brazil had arrived at a point of convergence sufficient to underpin a broad legislative framework. The bill was able to make progress because it took a 'something for everyone' approach to REDD+ (permitting revenues to flow to federal and state governments, high-deforestation and low-deforestation regions, private landowners and protected-area residents, indigenous communities and soya barons), while at the same time, including safeguards to allay the fears of forest-dwellers and their 
'socioculturalist' allies. The classic political economy question of 'who gets what, when and how' remains unanswered in relation to the precise mechanisms for sharing out REDD+ revenues. Similarly, the interpretation and enforcement of the safeguards promised in the negotiating text is likely to be the focus of continuing struggles as the Brazilian National REDD Regime progresses through regulatory definition and into implementation.

In these struggles, the stakes are high for indigenous people in Brazilian Amazonia. As we noted above, even the current small-scale REDD initiatives, most of which draw on the voluntary market, have generated concern and confusion among many indigenous groups, particularly those who have been targeted by 'carbon cowboys'. This situation is likely to worsen, as interest from carbon-market actors continues to intensify while what may be protracted discussions go on over the legal basis and regulatory framework for generation and trading of carbon credits in the region, leaving a cloud of legal uncertainty hanging over these kinds of projects. May and Millikan point out in a recent review of the policy context for REDD+ in Brazil that 'indigenous territories lie on lands under the control of the Union, from which the marketing of environmental services remains uncertain in terms of remuneration' (May and Millikan 2010: xi). Resolving this uncertainty will depend on the final outcome not only of the National REDD Regime process but also of the parallel initiative to define the national policy on the management of indigenous territories (PNGATI), which falls under the remit of FUNAI, the REDD-sceptical federal indigenous affairs agency.

Even with a clear and comprehensive legal framework in place, however, risks will remain. REDD+ initiatives may simply reinforce existing power configurations, through top-down design and implementation of projects in which state and private actors (federal and state agencies, local governments and international and national NGOs) capture the greater part of benefits from payments for environmental services at the expense of indigenous peoples and other forest communities. Brazil has robust Constitutional indigenous rights provisions and recognises international legal instruments like International Labour Organization (ILO) Convention 169 that guarantees the right of indigenous peoples to free, prior and informed consent, one of the key safeguards endorsed by the 'Principles and Criteria' process. Nevertheless, the country already stands accused of riding roughshod over this in order to push through 'national priority' infrastructure projects such as hydroelectric dams. Powerful economic and political interests may be able to claim the same 'national priority' status for REDD+ initiatives that undermine the land and livelihood rights of indigenous peoples, for example where private landowners contest their land claims or where there are overlaps between indigenous territories and state or federal protected areas (Rojas Garzón 2009). Even if the federal government is strongly committed to upholding indigenous rights claims, sub-national actors (many of them explicitly hostile to indigenous interests) may be able to take precedence. As Toni (2010) points out, Brazilian forestry and conservation policies have been undergoing a slow and steady decentralisation process and - as our discussion of state-level initiatives has indicated - this trend is likely to accelerate as REDD+ activities grow in importance.

While these issues have been widely discussed in the literature, one further key risk has not yet received sufficient attention. This is the prospect that future arrangements for the governance of REDD+ initiatives affecting indigenous territories will be unsuccessful because they simply fail to connect with the realities of indigenous resource management and political decision-making. The underlying logic of REDD is Western contract-based exchange: when payments are made to support forest protection on indigenous lands, a service is being purchased. Such an exchange assumes that a negotiation has taken place, that its object is clear to those involved and that legitimate agency is being exercised by those doing the negotiating otherwise it cannot be considered binding. Yet, if Bruno Latour is correct, the ontological basis of indigenous peoples' relationships with the forest is radically different from that assumed by the Western promoters of REDD. In other words, where the 'ecosystem services' that are on the table are defined by what Latour calls 'Western scientific mononaturalism' and have no equivalent category within indigenous conceptualisations of nature, it is by no means certain that both parties are in agreement on the object of their negotiations. ${ }^{8}$ Furthermore, indigenous political culture does not necessarily sanction delegated 
authority of the kind that operates in Western political or commercial negotiations (Shankland 2010b). Indigenous leaders interviewed during the study emphasised the difficulties they faced in involving their grassroots constituencies in the complex, fast-moving debate on REDD+ regulation. It is therefore premature to assume that the conditions exist for an agreement on REDD+ that can claim the binding consent of indigenous peoples.

This suggests that the negotiations, which Latour envisages as being necessary to bring to an end the 'war of the worlds', may not yet have taken place, for all the efforts to ensure indigenous participation in REDD+ debates, and for all the apparent convergence that has enabled Brazil to move forward with a legislative framework that seemingly has buy-in from all major stakeholders including indigenous peoples. An approach to REDD+ that is informed by climate justice principles should aspire to reach a state of

\section{Notes}

* Research for this article was carried out through the Political Economy of Low Carbon Climate Resilient Development project, coordinated by IDS and funded by the UK Department for International Development (DFID). The views expressed here are the views of the authors and do not represent the views or policies of IDS, DFID, or the UK government.

1 For simplicity, REDD and REDD+ are used interchangeably in the text.

2 In the aftermath of her successful participation in the Nagoya and Cancun meetings, Environment Minister, Izabella Teixeira, signalled her Ministry's determination to play the leading role in climate change policy, arguing strongly for Brazil to align its strategies on climate change and biodiversity conservation in order to consolidate its global leadership position and achieve maximum leverage in international negotiations (speech at the University of Brasília, 15 December 2010).

3 The 'Legal Amazon' is the political and administrative definition of Brazilian Amazonia, including the whole of eight states (Acre, Amapá, Amazonas, Mato Grosso, Pará, equiproportionality - that is, a distribution of REDD+ benefits that follows equity criteria proportionally based on the relevant aspects for which indigenous peoples can be held responsible, reflecting a range of factors including traditional knowledge and sustainable forestry practices, and the community's historical contribution to forest and natural resource conservation, alongside the amount of carbon secured. As indigenous peoples legally control a fifth of Brazilian Amazonia and hold much of the knowledge which will be needed to ensure sustainable management of the rest, failure to arrive at agreements with them that are both just and binding could critically undermine the prospects for success of REDD+ in Brazil and beyond. Achieving such agreements will require a genuine negotiation, not one in which the promoters of REDD proceed 'by generously offering to let the others in, on condition that they leave at the door all that is dear to them: their gods, their souls, their objects, their times and their spaces, in short, their ontology' (Latour 2002: 30).

Rondônia, Roraima and Tocantins) and part of a ninth (Maranhão).

4 For the full text of the 'Palmas Declaration', see: www4.ap.gov.br/jsp/noticias/news.jsp?ref= $7982 \& d t$ Day $=2009-06-26$. The text of the subsequent 'Macapá Declaration' can be found at http://www4.ap.gov.br/download/ carta_de_macapa.pdf

5 Interviews with participants in 'Indigenous Peoples and REDD+' workshop, Brasília, 15 September 2010.

6 IEB, the Instituto Internacional de Educação do Brasil (International Institute of Education in Brazil) was the local partner for this case study research.

7 This is a transliteration of the Portuguese term socioculturalista, which contrasts with the term socioambientalista (socioenvironmentalist), popular among 'social green' NGOs in Brazil (cf. Clapp and Dauvergne 2005).

8 Latour cites Eduardo Viveiros de Castro, whose 'perspectival' approach (2004) points out that, whereas we see one nature that is interpreted by many cultures, indigenous 'multinaturalism' presupposes that there are actually many different natural worlds. 


\section{References}

Amigos da Terra and 51 other signatories (2009) Carta de Belém: Os Efeitos das Mudanças Climáticas e a Política de REDD's, 3 October 2009, http://terradedireitos.org.br/biblioteca/ carta-de-belem-os-efeitos-das-mudancasclimaticas-e-a-politica-de-redds/ (accessed 27 January 2011)

Clapp, J. and Dauvergne, P. (2005) Paths to a Green World: The Political Economy of the Global Environment, Cambridge, MA: MIT Press

CMPCG (2010) Conferencia Mundial de los Pueblos sobre el Cambio Climático y los Derechos de la Madre Tierra: Acuerdo de los Pueblos, 22 October 2010, http://cmpcc.org/acuerdo-de-los-pueblos/ (accessed 27 January 2011)

Fearnside, P. (2008) 'The Roles and Movements of Actors in the Deforestation of Brazilian Amazonia', Ecology and Society 13.1: 23

Haas, P.M. (1992) 'Introduction: Epistemic Communities and International Policy Coordination', International Organization 46.1: $1-35$

Harvey, F. (2007) 'Beware the Carbon Offsetting Cowboys', Financial Times, 26 April

Holland, J. (2007) Tools for Institutional, Political, and Social Analysis of Policy Reform: A Sourcebook for Development Practitioners, Washington DC: World Bank

IPCC (2007) IPCC Fourth Assessment Report: Climate Change 2007 Synthesis Report, Geneva: Intergovernmental Panel on Climate Change

Latour, B. (2002) War of the Worlds: What About Peace?, Chicago: Prickly Paradigm Press

May, P.H and Millikan, B. (2010) 'The Context of REDD+ in Brazil: Drivers, Agents and Institutions', CIFOR Occasional Paper 55, Bogor Barat, Indonesia: Center for International Forestry Research (CIFOR)
McKinsey \& Company (2009) Caminhos para uma Economia de Baixa Emissão de Carbono no Brasil, São Paulo: McKinsey Brazilian Offices

Nelson, A. and Chomitz, K.M. (2009) Protected Area Effectiveness in Reducing Tropical Deforestation: A Global Analysis of the Impact of Protection Status, Washington DC: World Bank

Peskett, L. and Brockhaus, M. (2009) 'When REDD+ goes National: A Review of Realities, Opportunities and Challenges', in A.

Angelsen (ed.), Realising REDD+: National Strategy and Policy Options, Bogor Barat, Indonesia: Center for International Forestry Research (CIFOR)

Rojas Garzón, B. (2009) REDD en Territorios Indígenas de la Cuenca Amazónica: Serán los Pueblos Indígenas los Directos Beneficiarios?, Brasília: Instituto Socioambiental

Shankland, A. (2010a) 'The Indigenous Peoples' Movement, "Forest Citizenship" and Struggles over Health Services in Acre, Brazil', in V.S.P. Coelho and B. Von Lieres (eds), Mobilising for Democracy: Citizen Action and the Politics of Public Participation, London: Zed

Shankland, A. (2010b) 'Speaking for the People: Representation and Health Policy in the Brazilian Amazon', DPhil dissertation, IDS, University of Sussex

Toni, F. (2010) 'Decentralization and REDD+ in Brazil', Paper for the 'Oaxaca Workshop on Forest Governance, Decentralization and REDD+ in Latin America and the Caribbean', 31 August-3 September, Mexico Voivodic, M.; Gomes, R.; Moreira, P. et al. (2010) 'Developing Safeguards for REDD-Plus: The Importance of a Collaborative Approach', in C. Foley (ed.), Everything is Connected: Climate and Biodiversity in a Fragile World, Brasília: British Embassy 